\title{
Kisspeptin receptor agonist (FTM080) increased plasma concentrations of luteinizing hormone in anestrous ewes
}

Brian K Whitlock, Joseph A Daniel, Lisa L Amelse, Valeria M Tanco, Kelly A Chameroy, F Neal Schrick

Kisspeptin receptor (KISS1R) agonists with increased half-life and similar efficacy to kisspeptin in vitro may provide beneficial applications in breeding management of many species. However, many of these agonists have not been tested in vivo. These studies were designed to test and compare the effects of a KISS1R agonist (FTM080) and kisspeptin on luteinizing hormone (LH) in vivo. In experiment 1 (pilot study), sheep were treated with FTM080 (500 pmol/kg BW) or sterile water (VEH) intravenosuly. Blood was collected every 15 min before ( $1 \mathrm{hr}$ ) and after ( $1 \mathrm{hr}$ ) treatment. In experiment 2, sheep were treated with KP-10 (human Metastin 45-54; $500 \mathrm{pmol} / \mathrm{kg} \mathrm{BW}$ ), one of three dosages of FTM080 [500 (FTM080:500), 2500 (FTM080:2500), or 5000 (FTM080:5000) pmol/kg BW], or VEH intravenously. Blood was collected every $15 \mathrm{~min}$ before ( $1 \mathrm{hr}$ ) and after (4 hr) treatment. In experiment 1, FTM080:500 increased ( $<$ < 0.05) plasma LH concentrations when compared to VEH. The area under the curve (AUC) of LH following FTM080:500 treatment was also increased $(P<0.05)$. In experiment 2 , plasma LH concentrations increased $(P<0.05)$ following treatment with KP-10 and FTM080:5000 when compared to VEH and FTM080:500. The AUC of LH following KP-10 was greater than $(P<0.05)$ all other treatments and the AUC of LH following FTM080:5000 was greater than $(P<0.05)$ all treatments except KP-10. These data provide evidence to suggest that FTM080 stimulates the gonadotropic axis of ruminants in vivo. Any increased half-life and comparable efficacy of FTM080 to KP-10 in vitro does not appear to translate to in vivo in sheep. 
TITLE

2 KISSPEPTIN RECEPTOR AGONIST (FTM080) INCREASED PLASMA

3 CONCENTRATIONS OF LUTEINIZING HORMONE IN ANESTROUS EWES

4 Brian K. Whitlock*1, Joseph A. Daniel², Lisa L. Amelse', Valeria M. Tanco1, Kelly A.

5 Chameroy $^{1}$, and F. Neal Schrick ${ }^{3}$

$6{ }^{1}$ Department of Large Animal Clinical Sciences, College of Veterinary Medicine, The University

7 of Tennessee, Knoxville, TN 37996 USA

$8 \quad{ }^{2}$ Department of Animal Science, Berry College, Mt. Berry, GA 30149

$9{ }^{3}$ Department of Animal Science, The University of Tennessee, Knoxville, TN 37996

10 Correspondence: Brian K. Whitlock

11

12

13

14

15

16

17 Key Words: Kisspeptin, Agonist, Luteinizing hormone, Sheep

\section{ABSTRACT}

Background/Aims: Kisspeptin receptor (KISS1R) agonists with increased half-life and

20 similar efficacy to kisspeptin in vitro may provide beneficial applications in breeding

21 management of many species. However, many of these agonists have not been tested in vivo. 
22 These studies were designed to test and compare the effects of a KISS1R agonist (FTM080) and

23 kisspeptin on luteinizing hormone (LH) in vivo.

24 Methods: Experiment 1 (pilot study): Sheep were treated with FTM080 (500 pmol/kg

$25 \mathrm{BW})$ or sterile water (VEH) intravenosuly. Blood was collected every $15 \mathrm{~min}$ before (1 hr) and

26 after (1 hr) treatment. Experiment 2: Sheep were treated with KP-10 (human Metastin 45-54;

$27500 \mathrm{pmol} / \mathrm{kg} \mathrm{BW}$ ), one of three dosages of FTM080 [500 (FTM080:500), 2500 (FTM080:2500),

28 or 5000 (FTM080:5000) pmol/kg BW], or VEH intravenously. Blood was collected every 15

$29 \min$ before $(1 \mathrm{hr})$ and after $(4 \mathrm{hr})$ treatment.

Results: Experiment 1: FTM080:500 increased $(\mathrm{P}<0.05)$ plasma LH concentrations

31 when compared to VEH. The area under the curve (AUC) of LH following FTM080:500

32 treatment was also increased $(\mathrm{P}<0.05)$. Experiment 2: Plasma LH concentrations increased $(\mathrm{P}<$

33 0.05) following treatment with KP-10 and FTM080:5000 when compared to VEH and

34 FTM080:500. The AUC of LH following KP-10 was greater than $(\mathrm{P}<0.05)$ all other treatments

35 and the AUC of LH following FTM080:5000 was greater than $(\mathrm{P}<0.05)$ all treatments except

$36 \mathrm{KP}-10$.

Conclusions: These data provide evidence to suggest that FTM080 stimulates the

38 gonadotropic axis of ruminants in vivo. Any increased half-life and comparable efficacy of

39 FTM080 to KP-10 in vitro does not appear to translate to in vivo in sheep.

\section{INTRODUCTION}

Reproduction requires precise interactions among the brain, the pituitary, and the gonads

42 (gonadotropic-axis). Gonadotropin-releasing hormone ( $\mathrm{GnRH})$ from the hypothalamus has long

43 been considered a major regulator of the gonadotropic-axis because it controls the secretion of 
44 the gonadotropins luteinizing hormone ( $\mathrm{LH})$ and follicle-stimulating hormone from the pituitary,

45 the production of sexual hormones, and gametes by the gonads [1]. Until recently many

46 unknowns remained in our understanding of the neuroendocrine mechanisms controlling the

47 release of GnRH. For example, in female mammals estradiol induces a strong increase in GnRH

48 release during the follicular phase of the estrous cycle, leading to preovulatory GnRH and LH

49 surges and ultimately ovulation [2-5]. However, the pathways and the hierarchy of mechanisms

50 involved in the regulation of GnRH release are only partially understood.

51 Kisspeptin recently emerged as a major regulator of the gonadotropic-axis located

52 "upstream" of the GnRH cell population in the hypothalamus. Kisspeptin was first discovered

53 and noted for its role in the inhibition of cancer cell metastasis [6]. The central functions of

54 kisspeptin and the kisspeptin receptor (KISS1R) in regulating mammalian reproductive

55 development and fertility were unnoticed until 2003, when three groups independently reported

56 the presence of deletion and inactivating mutations of KISS1R in humans [7, 8] and mice [7, 9]

57 suffering from hypogonadotropic hypogonadism; a syndrome characterized by delayed or absent

58 pubertal development secondary to gonadotropin deficiency. It was later discovered that

59 kisspeptin was necessary for GnRH release from the hypothalamus and subsequent secretion of

60 LH from the anterior pituitary [7-10]. Kisspeptin is involved in sexual differentiation of the

61 brain, timing of puberty, regulation of gonadotropin secretion by gonadal hormones, and the

62 control of fertility by metabolic and environmental cues [11]. With the recognition that

63 kisspeptin is a major regulator of the gonadotropic-axis and a potent stimulator of gonadotropin

64 secretion has come the notion that it could be used to manipulate reproduction. Indeed,

65 exogenous administration of kisspeptin has been shown to stimulate LH and follicle-stimulation

66 hormone secretion in many species [12]. However, few experiments have been designed to 
67 evaluate the potential of kisspeptin to manipulate reproduction in animals. Intravenous infusion

68 of kisspeptin to sheep in the non-breeding season elevated gonadotropin secretion and caused

69 ovulation [13]. The demonstration that intravenous infusion of kisspeptin can stimulate

70 ovulation in seasonally anestrous female sheep offers a potential means of manipulating the

71 reproductive axis and ultimately fertility in a multitude of species. However, kisspeptin may be

72 of limited clinical use because of the short circulating half-life [14-17]. Rational modification of

73 KISS1R agonists were synthesized to be resistant to matrix metalloproteinase (MMP) activity

74 and/or found to have increased half-life in murine serum (FTM145 and FTM080), and to have

75 comparable binding affinity and efficacy in vitro to kisspeptin [18]. However, in vivo activities

76 of these peptides have not yet been studied. Thus, the present experiments were designed to

77 determine and compare the effect of a novel KISS1R agonist (FTM080) [18, 19] and kisspeptin

78 on plasma LH concentrations in seasonally anestrus female sheep.

\section{MATERIALS AND METHODS}

All procedures were approved by the Berry College (Rome, GA) Institutional Animal Care and Use Committee (Protocol No. 2011/12-010). Adult parous Katahdin female sheep were used in this experiment. Sheep were housed at the Ruminant Research Unit at Berry College $\left(\right.$ Latitude $=34^{\circ} 18^{\prime} 8.33^{\prime \prime} \mathrm{N}$; Longitude $\left.=85^{\circ} 11^{\prime} 45.29^{\prime \prime} \mathrm{W}\right)$, exposed to average ambient temperature $\left(25^{\circ} \mathrm{C}\right.$ average daily temperature) and summer photoperiod (14:10 [L:D] hr) throughout the experiments (June), and fed a maintenance diet calculated to meet $100 \%$ of daily requirements [20]. During the experiments sheep were kept in individual pens $(1.2 \mathrm{X} 1.2 \mathrm{~m})$ to facilitate IV injection and serial blood collections.

The effects of a novel KISS1R agonist (FTM080: 4-fluorobenzoyl-Phe-Gly-Leu-ArgTrp- $\mathrm{NH}_{2}$; Graduate School of Pharmaceutical Sciences, Kyoto University) $[18,19]$ and KP-10 (a 
90 biologically active C-terminally amidated cleavage fragment of kisspeptin, human Metastin 45-

91 54, 4389-v, Peptide Institute Inc., Osaka, Japan) on plasma LH concentrations in anestrous sheep

92 was tested. To reduce the influence of sex steroids on the kisspeptin-KISS1R system, studies

93 were conducted during a long photoperiod to increase the likelihood of ewes being anestrous

94 [21]. In addition, blood samples were collected before, during, and after the experiments (7 days

95 between samples over three consecutive weeks) and assayed to determine progesterone

96 concentrations. Data from animals with circulating progesterone concentrations greater than 1

$97 \mathrm{ng} / \mathrm{mL}$ (indicating active luteal tissue and therefore cyclicity) were excluded from the analysis.

98 To facilitate treatment administration and blood sampling, each animal was fitted with an

99 indwelling intravenous jugular catheter the day before experimentation.

$100 \quad$ Experiment 1: Eight sheep [41.6 $\pm(\mathrm{SEM}) 1.3 \mathrm{~kg}]$ were treated with FTM080 (500

$101 \mathrm{pmol} / \mathrm{kg} \mathrm{BW}$; FTM080:500; diluted in sterile water; $\mathrm{n}=4$ ) or sterile water (Vehicle; VEH; $\mathrm{n}=4$ )

102 in a 2-mL bolus via the jugular cannula. Serial blood samples (every $15 \mathrm{~min}$; 3-mL each) were

103 collected before (for $1 \mathrm{hr}$ ) and after (for $1 \mathrm{hr}$ ) treatment. Blood was collected into tubes

104 containing $7.5 \mathrm{mg}$ EDTA. Plasma was stored at $-20^{\circ} \mathrm{C}$ for radioimmunoassay (RIA) of LH and

105 progesterone.

106 Experiment 2: Twenty-one sheep [48.2 $\pm 5.1 \mathrm{~kg}]$ were used in this experiment. Sheep

107 received one of five treatments [sterile water (Vehicle; VEH; $\mathrm{n}=5$ ), KP-10 diluted in sterile

108 water $(500 \mathrm{pmol} / \mathrm{kg} \mathrm{BW} ; \mathrm{n}=4)$, or FTM080 diluted in sterile water [500 (FTM080:500; $\mathrm{n}=4)$,

$1092500($ FTM080:2500; $\mathrm{n}=4)$, or $5000($ FTM080:5000; $\mathrm{n}=4) \mathrm{pmol} / \mathrm{kg} \mathrm{BW})]$ in 2-mL bolus via

110 the jugular cannula. Samples were collected and handled in the same manner as described in

111 Experiment 1 except blood samples were collected for a total of $4 \mathrm{hr}$ after treatment. 
113 supplied by the National Hormone and Pituitary Program of NIDDK as previously described

114 [22]. Limit of detection and intra-assay and inter-assay coefficient of variance were $0.125 \mathrm{ng} / \mathrm{ml}$

115 and $5.5 \%$ and $9.9 \%$ for the LH assays, respectively. Plasma progesterone concentrations were

116 determined using the Coat-a-Count ${ }^{\circledR}$ Progesterone RIA kit (Siemens, Los Angeles, CA, USA)

117 [23-26]. Limit of detection and intra-assay coefficients of variance for the progesterone assay

118 were $0.1 \mathrm{ng} / \mathrm{mL}$ and $14.9 \%$, respectively.

119 For Experiments One and Two circulating concentrations of LH were tested for effect of

120 treatment, time, and treatment by time interaction using ANOVA procedures for repeated

121 measures with JMP Software (version 7 SAS Inst. Inc., Cary, NC). Area under the LH

122 concentration curve pre (-60 to $0 \mathrm{~min})$ and post ( 0 to $60 \mathrm{~min})$ treatment was calculated using the

123 trapezoid method with MSExcel Software. Area under the LH curve was tested for effect of

124 treatment, period (pre- or post-treatment), and treatment by period interaction using ANOVA

125 procedures for repeated measures with JMP Software (version 7, SAS Inst. Inc., Cary, NC).

126 Means separation was performed using Student's T test when appropriate.

\section{RESULTS}

128 Experiment 1: Two ewes (one per treatment) were excluded from the analysis and results

129 because their plasma progesterone concentrations were greater than $1 \mathrm{ng} / \mathrm{mL}$ (2.60 and $1.70 \mathrm{ng} /$

$130 \mathrm{~mL})$ thus plasma LH concentrations from six ewes $(\mathrm{n}=3)$ were analyzed and reported. Plasma

131 progesterone concentrations for the remainder of the animals were less than $1 \mathrm{ng} / \mathrm{mL}[0.12 \pm$

$1320.08(\mathrm{SEM}) \mathrm{ng} / \mathrm{mL}]$. Mean $\pm \mathrm{SEM}$ plasma LH concentrations before treatment were $0.31 \pm$

$1330.16 \mathrm{ng} / \mathrm{mL}$ and $0.14 \pm 0.06 \mathrm{ng} / \mathrm{mL}$ for animals treated with VEH and FTM080:500,

134 respectively. Mean plasma LH concentrations for the period after treatment were $0.24 \pm 0.04$ 
$135 \mathrm{ng} / \mathrm{mL}$ and $0.73 \pm 0.08 \mathrm{ng} / \mathrm{mL}$ for animals treated with VEH and FTM080:500, respectively.

136 There was an effect of time $(\mathrm{P}=0.0019)$ and a treatment by time interaction $(\mathrm{P}=0.0009)$ on

137 plasma LH concentrations. Plasma LH concentrations for FTM080:500 treated animals were

138 greater than $(\mathrm{P}<0.05) \mathrm{VEH}$ from 0 to 45 minutes following treatment (Figure 1A).

An effect of period (pre- and post-treatment) $(\mathrm{P}=0.0464)$ and a period by treatment

140 interaction $(\mathrm{P}=0.0150)$ was found when analyzing the area under the LH curve. The area under

141 the curve of LH for FTM080:500 treated animals was greater than $(\mathrm{P}<0.05)$ VEH from 0 to 60

142 minutes following treatment (Figure 1B).

$143 \quad$ Experiment 2: One ewe (VEH group) was excluded from the analysis and results

144 because of high plasma progesterone concentrations (7 days post-experiment; $2.50 \mathrm{ng} / \mathrm{mL}$ ).

145 Plasma LH concentrations from a total of 20 ewes $(n=4)$ were analyzed and reported. Plasma

146 progesterone concentrations for the 20 animals included in the analysis were less than $1 \mathrm{ng} / \mathrm{mL}$

$147(0.16 \pm 0.01 \mathrm{ng} / \mathrm{mL})$ before and after the experiment. Mean \pm SEM plasma LH concentrations

148 were $0.59 \pm 0.37 \mathrm{ng} / \mathrm{mL}, 0.78 \pm 0.38 \mathrm{ng} / \mathrm{mL}, 0.43 \pm 0.24 \mathrm{ng} / \mathrm{mL}, 0.58 \pm 0.37 \mathrm{ng} / \mathrm{mL}$, and $0.53 \pm$

$1490.28 \mathrm{ng} / \mathrm{mL}$ before treatment with VEH, KP-10, FTM080:500, FTM080:2500, and

150 FTM080:5000 pmol/kg, respectively. Mean plasma LH concentrations were $1.35 \pm 0.20 \mathrm{ng} / \mathrm{mL}$,

$1511.93 \pm 0.37 \mathrm{ng} / \mathrm{mL}, 0.97 \pm 0.13 \mathrm{ng} / \mathrm{mL}, 0.94 \pm 0.13 \mathrm{ng} / \mathrm{mL}$, and $1.29 \pm 0.29 \mathrm{ng} / \mathrm{mL}$ for the period

152 after treatment with VEH, KP-10, FTM080:500, FTM080:2500, and FTM080:5000 pmol/kg,

153 respectively. There was an effect of treatment $(\mathrm{P}=0.0134)$ on mean plasma LH concentrations.

154 Mean plasma LH concentration for the period following treatment with KP-10 (1.93 \pm 0.37

$155 \mathrm{ng} / \mathrm{mL}$ ) was greater than all treatments except FTM080:5000. There was also an effect of time

$156(\mathrm{P}<0.0001)$ and an interaction of treatment and time $(\mathrm{P}<0.0001)$ on plasma LH concentrations.

157 Plasma LH concentrations following treatment with KP-10 were greater than $(\mathrm{P}<0.05)$ the VEH 
158 through the 45-min sample, FTM080:500 at the 30- and 45-min samples, and FTM080:2500 at

159 30-min (Figure 2A). Plasma LH concentrations following FTM080:5000 was greater than $(\mathrm{P}<$

160 0.05) VEH through the 30-min sample and FTM080:500 at the 15-min samples (Figure 2A).

161 There was an effect of treatment $(\mathrm{P}<0.0001)$, period [pre-treatment (-60 to 0 min); 1

162 hour post-treatment ( 0 to $60 \mathrm{~min}) ; \mathrm{P}<0.0001]$, and an interaction of treatment and period $(\mathrm{P}<$

163 0.0001) on area under the curve (AUC) of plasma LH concentrations. The 1 hour post-treatment

164 AUC of LH following KP-10 was greater than $(\mathrm{P}<0.05)$ all other treatments and the 1 hour

165 post-treatment AUC of LH following FTM080:5000 was greater than $(\mathrm{P}<0.05)$ all treatments

166 except KP-10 (Figure 2B). The AUC of LH in the 1 hour post-treatment period was greater than

167 (P < 0.05) the AUC of LH in the pre-treatment period $(-60$ to $0 \mathrm{~min})$ for FTM080:500 and

168 FTM080:2500 (Figure 2B).

169 DISCUSSION

$170 \quad$ FTM080 was recently identified as a potent KISS1R agonist by structure-activity

171 relationship studies on kisspeptin [19,27]. It has been reported that kisspeptin is inactivated by

172 the cleavage of the Gly-Leu peptide bond in the C-terminal region by MMPs [28]. Since

173 kisspeptin and FTM080 share a common sequence (Phe-Gly-Leu-Arg) of the MMP-mediated

174 cleavage site, FTM080 would be also deactivated by MMP-mediated digestion. However, the

175 half-life of FTM080 in murine serum (6.6 h) is greater than that of KP-10 (completely digested

176 within $1 \mathrm{~h}$ ). Substitution of the Gly-Leu dipeptide moiety in FTM080 and KP-10 with

177 appropriate dipeptide isosteres resulted in peptides (e.g. FTM145) resistant to degradation by

178 MMP-2 and -9, more stable in murine serum (e.g. compound FTM145 half-life $=38$ h), while

179 maintaining bioactivity for KISS1R in vitro [18]. However, in vivo activities of these peptides

180 were not previously studied. Studies on pentapeptides derived from C-terminal kisspeptin 
181 fragments have been mainly focused on the design of analogs with superagonistic properties in

182 vitro. Many previously developed pentapeptides, with apparent full agonistic activity at the

183 KISS1R in cellular models, have not been evaluated in terms of gonadotropin secretion in vivo.

184 When in vivo studies are conducted those observation do not always agree with findings from in

185 vitro experimentation. For example, the attributes of FTM145 observed in vitro (resistance to

186 MMP activity, greater stability in murine serum, and comparable bioactivity for KISS1R) were

187 not recognized/observed in terms of gonadotropin secretion in vivo as FTM145 had no effect on

188 plasma LH concentrations in anestrous ewes (Whitlock, unpublished).

189 Results of the present study revealed that intravenous FTM080 stimulated an increase of

190 plasma LH concentrations in anestrous sheep. In Experiment 1 (pilot study), plasma LH

191 concentrations increased approximately 7-fold between 0 and 45 minutes following intravenous

192 treatment with FTM080 (from 0.14 to $0.97 \mathrm{ng} / \mathrm{mL}$ ). The magnitude and duration of the LH-

193 response following treatment with FTM080 in Experiment 1 was similar to previous

194 observations in ovariectomized sheep given comparable doses of KP-10 [13, 29].

195 In Experiment 2 (a comparison of the effects of FTM080 and KP-10 on plasma LH

196 concentrations in sheep) KP-10 stimulated the greatest magnitude and duration of an increase in

197 LH secretion (0.64 to $5.55 \mathrm{ng} / \mathrm{mL}$ and $45 \mathrm{~min}$, respectively). Caraty et al., [13] reported that an

198 intravenous bolus of KP-10 of approximately half the molar dose used in this experiment (500

$199 \mathrm{pmol} / \mathrm{kg}$ ) increased concentrations of LH in plasma of seasonally acyclic ewes from $0.2 \mathrm{ng} / \mathrm{mL}$

200 to $8.0 \mathrm{ng} / \mathrm{mL}$ which was similar to the response observed here. Although FTM080 did elicit a

201 comparable LH-response ( 0.76 to $4.58 \mathrm{ng} / \mathrm{mL}$ ), the dose necessary was 10 -fold greater than the

202 dose of KP-10 used (5000 versus $500 \mathrm{pmol} / \mathrm{kg}$, respectively). Moreover, although the in vitro

203 half-life of FTM080 was greater than KP-10 [18], the duration of the LH-response following an 
204 intravenous dose of FTM080 was less than the duration following a 10-fold lesser dose of KP-10

205 (30 min versus $45 \mathrm{~min}$, respectively).The shorter duration of the LH-response following

206 treatment with FTM080 might simply be related to a difference in LH peak response (timing and

207 possibly amplitude). It appears that LH-response slopes following treatment with FTM080 and

208 KP-10 have a similar decay (are parallel).

209 In vitro screening and assays are useful to select agonist analogs for further in vivo

210 studies. By improving biological stability while maintaining in vitro agonistic and receptor

211 binding activity to KISS1R Asami et al., [30] identified the potent kisspeptin agonist analogue,

212 TAK-683. TAK-683 was administered in several mammalian species including goats [31] and

213 men [32] demonstrating excellent gonadotropin releasing activity in vivo at low doses. However,

214 in vitro and in vivo activity/potency of KISS1R agonists do not always agree [33, 34]. For

215 instance, while KP-10 analog [dY $]^{1} \mathrm{KP}$ bound to the KISS1R with a 4-fold lower affinity and had

216 similar potency in vitro it had a more potent effect (4-fold) on LH than KP-10 in vivo [34].

217 Alternatively, another KP-10 analog, ANA5, bound with higher affinity to the KISS1R than

218 kisspeptin but it was not more potent in vitro and less potent in vivo than KP-10 [34]. Thus

219 although some kisspeptin analogs may act as KISS1R superagonists in specific in vitro systems,

220 they may not have greater activity than kisspeptin in vivo.

It is interesting to speculate on mechanisms for the different responses obtained between

222 FTM080 and KP-10 and why responses to FTM080 in sheep do not agree with those observed in

223 vitro. There is the possibility that shorter kisspeptin analogs (FTM080 is pentapeptide) have

224 some limitation in terms of efficacy. The C-terminal amino acids of KP-10 (decapeptide that is a

225 biologically active C-terminally amidated cleavage fragment of kisspeptin) are critical for

226 efficient KISS1R binding [10] resulting overall in a greater focus on the screening of decapeptide 
227 instead of pentapeptide analogs of kisspeptin as potential KISS1R agonists. The difference in

228 response observed here might also be the result of the animal model used for the in vivo

229 experimentations. While previous in vitro assays to determine the bioactivity of FTM080 were

230 conducted with human KISS1R [19, 27] the activity of FTM080 to sheep KISS1R has not been

231 investigated. Contrarily, similar doses of kisspeptin have been administered to various species

232 and various routes resulting very often in similar and comparable responses [35]. Differences in

233 tissue distribution of KP-10 and FTM080 may be another possibility to explain differential in

234 vivo efficacy. Only centrally, but not peripherally, administered KP-10 increased serum

235 concentrations of growth hormone in sheep [29]. Likewise, only centrally, but not peripherally,

236 administered KP-10 induced c-Fos in GnRH neurons, suggesting that differential site of action of

237 kisspeptin causes differential gonadotropin releasing efficacy in vivo [36]. Differences in tissue

238 distribution, especially at the hypothalamus, of FTM080 and KP-10 were not determined in this

239 study. Pharmacokinetic profiles, including but not limited to clearance of FTM080, is another

240 possible explanation for the different LH responses observed between FTM080 and KP-10.

241 Higher clearance of FTM080 from the sheep circulation than KP-10 could be hypothesized to

242 rationalize the lesser in vivo activity.

In conclusion, these data provide evidence to suggest that FTM080, a KISS1R agonist,

244 stimulates the gonadotropic axis of ruminants in vivo. However, the increased half-life and

245 comparable efficacy of FTM080 to KP-10 in vitro [18] does not appear to translate to longer

246 duration of efficacy in vivo in sheep.

\section{REFERENCES}

2481 Knobil E: Discovery of the hypothalamic gonadotropin-releasing hormone pulse 249 generator and of its physiologic significance. 1992. American journal of obstetrics and 250 gynecology 2005;193:1765-1766. 
2512 Xia L, Van Vugt D, Alston EJ, Luckhaus J, Ferin M: A surge of gonadotropin-releasing

252 hormone accompanies the estradiol-induced gonadotropin surge in the rhesus monkey.

253 Endocrinology 1992;131:2812-2820.

2543 Moenter SM, Caraty A, Locatelli A, Karsch FJ: Pattern of gonadotropin-releasing

255 hormone (gnrh) secretion leading up to ovulation in the ewe: Existence of a preovulatory gnrh

256 surge. Endocrinology 1991;129:1175-1182.

2574 Sarkar DK, Chiappa SA, Fink G, Sherwood NM: Gonadotropin-releasing hormone surge

258 in pro-oestrous rats. Nature 1976;264:461-463.

2595 Clarke IJ, Cummins JT, Jenkin M, Phillips DJ: The oestrogen-induced surge of $\mathrm{lh}$

260 requires a 'signal' pattern of gonadotrophin-releasing hormone input to the pituitary gland in the

261 ewe. J Endocrinol 1989;122:127-134.

2626 Lee JH, Miele ME, Hicks DJ, Phillips KK, Trent JM, Weissman BE, Welch DR: Kiss-1,

263 a novel human malignant melanoma metastasis-suppressor gene. J Natl Cancer Inst

264 1996;88:1731-1737.

2657 Seminara SB, Messager S, Chatzidaki EE, Thresher RR, Acierno JS, Jr., Shagoury JK,

266 Bo-Abbas Y, Kuohung W, Schwinof KM, Hendrick AG, Zahn D, Dixon J, Kaiser UB,

267 Slaugenhaupt SA, Gusella JF, O'Rahilly S, Carlton MB, Crowley WF, Jr., Aparicio SA, Colledge

268 WH: The gpr54 gene as a regulator of puberty. N Engl J Med 2003;349:1614-1627.

2698 de Roux N, Genin E, Carel JC, Matsuda F, Chaussain JL, Milgrom E: Hypogonadotropic

270 hypogonadism due to loss of function of the kiss1-derived peptide receptor gpr54. Proc Natl

271 Acad Sci U S A 2003;100:10972-10976.

2729 Funes S, Hedrick JA, Vassileva G, Markowitz L, Abbondanzo S, Golovko A, Yang S,

273 Monsma FJ, Gustafson EL: The kiss-1 receptor gpr54 is essential for the development of the

274 murine reproductive system. Biochem Biophys Res Commun 2003;312:1357-1363.

27510 Roseweir AK, Kauffman AS, Smith JT, Guerriero KA, Morgan K, Pielecka-Fortuna J,

276 Pineda R, Gottsch ML, Tena-Sempere M, Moenter SM, Terasawa E, Clarke IJ, Steiner RA,

277 Millar RP: Discovery of potent kisspeptin antagonists delineate physiological mechanisms of

278 gonadotropin regulation. J Neurosci 2009;29:3920-3929.

27911 Roa J, Navarro VM, Tena-Sempere M: Kisspeptins in reproductive biology: Consensus

280 knowledge and recent developments. Biol Reprod 2011;85:650-660.

$281 \quad 12$ Tena-Sempere M: Gpr54 and kisspeptin in reproduction. Hum Reprod Update

282 2006;12:631-639.

28313 Caraty A, Smith JT, Lomet D, Ben Said S, Morrissey A, Cognie J, Doughton B, Baril G,

284 Briant C, Clarke IJ: Kisspeptin synchronizes preovulatory surges in cyclical ewes and causes

285 ovulation in seasonally acyclic ewes. Endocrinology 2007;148:5258-5267.

28614 Kotani M, Detheux M, Vandenbogaerde A, Communi D, Vanderwinden JM, Le Poul E,

287 Brezillon S, Tyldesley R, Suarez-Huerta N, Vandeput F, Blanpain C, Schiffmann SN, Vassart G,

288 Parmentier M: The metastasis suppressor gene kiss-1 encodes kisspeptins, the natural ligands of

289 the orphan g protein-coupled receptor gpr54. J Biol Chem 2001;276:34631-34636.

29015 Dhillo WS, Chaudhri OB, Patterson M, Thompson EL, Murphy KG, Badman MK,

291 McGowan BM, Amber V, Patel S, Ghatei MA, Bloom SR: Kisspeptin-54 stimulates the

292 hypothalamic-pituitary gonadal axis in human males. J Clin Endocrinol Metab 2005;90:6609-

2936615.

$29416 \quad$ Plant TM, Ramaswamy S, Dipietro MJ: Repetitive activation of hypothalamic g protein-

295 coupled receptor 54 with intravenous pulses of kisspeptin in the juvenile monkey (macaca 
296 mulatta) elicits a sustained train of gonadotropin-releasing hormone discharges. Endocrinology

297

29817 Liu Z, Ren C, Jones W, Chen P, Seminara SB, Chan YM, Smith NF, Covey JM, Wang J, 299 Chan KK: Lc-ms/ms quantification of a neuropeptide fragment kisspeptin-10 (nsc 741805) and

300

301

302

303

304

305

306

307

308

309

310

311

312

313

314

315

316

317

318

319

320

321

322

323

324

325

326

327

328

329

330

331

332

333

334

335

336

337

338

339

340 characterization of its decomposition product and pharmacokinetics in rats. Journal of chromatography B, Analytical technologies in the biomedical and life sciences 2013;926:1-8. 18 Tomita K, Oishi S, Ohno H, Peiper SC, Fujii N: Development of novel g-protein-coupled receptor 54 agonists with resistance to degradation by matrix metalloproteinase. J Med Chem 2008;51:7645-7649.

19 Tomita K, Oishi S, Cluzeau J, Ohno H, Navenot JM, Wang ZX, Peiper SC, Akamatsu M, Fujii N: Sar and qsar studies on the n-terminally acylated pentapeptide agonists for gpr54. J Med Chem 2007;50:3222-3228.

20 NRC: Nutrient requirments of sheep, ed 6th rev. ed. Washington, DC, Natl. Acad. Sci., 1985.

21 Smith JT, Clay CM, Caraty A, Clarke IJ: Kiss-1 messenger ribonucleic acid expression in the hypothalamus of the ewe is regulated by sex steroids and season. Endocrinology 2007;148:1150-1157.

22 Coleman ES, Elsasser TH, Kemppainen RJ, Coleman DA, Sartin JL: Effect of endotoxin on pituitary hormone secretion in sheep. Neuroendocrinology 1993;58:111-122.

23 Minton JE, Coppinger TR, Spaeth CW, Martin LC: Poor reproductive response of anestrous suffolk ewes to ram exposure is not due to failure to secrete luteinizing hormone acutely. J Anim Sci 1991;69:3314-3320.

24 Srikandakumar A, Ingraham RH, Ellsworth M, Archbald LF, Liao A, Godke RA:

Comparison of a solid-phase, no-extraction radioimmunoassay for progesterone with an extraction assay for monitoring luteal function in the mare, bitch, and cow. Theriogenology 1986;26:779-793.

25 Reimers TJ, Lamb SV, Bartlett SA, Matamoros RA, Cowan RG, Engle JS: Effects of hemolysis and storage on quantification of hormones in blood samples from dogs, cattle, and horses. Am J Vet Res 1991;52:1075-1080.

26 Colazo MG, Ambrose DJ, Kastelic JP, Small JA: Comparison of 2 enzyme immunoassays and a radiimmunoasssay for measurement of progesterone concentrations in bovine plasma, skim milk, and whole milk. Canadian Journal of Veterinary Research-Revue Canadienne De Recherche Veterinaire 2008;72:32-36.

27 Niida A, Wang Z, Tomita K, Oishi S, Tamamura H, Otaka A, Navenot JM, Broach JR, Peiper SC, Fujii N: Design and synthesis of downsized metastin (45-54) analogs with maintenance of high gpr54 agonistic activity. Bioorg Med Chem Lett 2006;16:134-137. 28 Takino T, Koshikawa N, Miyamori H, Tanaka M, Sasaki T, Okada Y, Seiki M, Sato H: Cleavage of metastasis suppressor gene product kiss-1 protein/metastin by matrix metalloproteinases. Oncogene 2003;22:4617-4626.

29 Whitlock BK, Daniel JA, Wilborn RR, Maxwell HS, Steele BP, Sartin JL: Interaction of kisspeptin and the somatotropic axis. Neuroendocrinology 2010;92:178-188.

30 Asami T, Nishizawa N, Matsui H, Nishibori K, Ishibashi Y, Horikoshi Y, Nakayama M, Matsumoto S, Tarui N, Yamaguchi M, Matsumoto H, Ohtaki T, Kitada C: Design, synthesis, and biological evaluation of novel investigational nonapeptide kiss $1 \mathrm{r}$ agonists with testosteronesuppressive activity. J Med Chem 2013;56:8298-8307. 
34131 Tanaka T, Ohkura S, Wakabayashi Y, Kuroiwa T, Nagai K, Endo N, Tanaka A, Matsui

$342 \mathrm{H}$, Kusaka M, Okamura H: Differential effects of continuous exposure to the investigational

343 metastin/kisspeptin analog tak-683 on pulsatile and surge mode secretion of luteinizing hormone

344 in ovariectomized goats. J Reprod Dev 2013;59:563-568.

34532 Scott G, Ahmad I, Howard K, MacLean D, Oliva C, Warrington S, Wilbraham D,

346 Worthington P: Double-blind, randomized, placebo-controlled study of safety, tolerability,

347 pharmacokinetics and pharmacodynamics of tak-683, an investigational metastin analogue in

348 healthy men. British journal of clinical pharmacology 2013;75:381-391.

34933 Gutierrez-Pascual E, Leprince J, Martinez-Fuentes AJ, Segalas-Milazzo I, Pineda R, Roa

350 J, Duran-Prado M, Guilhaudis L, Desperrois E, Lebreton A, Pinilla L, Tonon MC, Malagon MM,

351 Vaudry H, Tena-Sempere M, Castano J: In vivo and in vitro structure-activity relationships and

352 structural conformation of kisspeptin-10-related peptides. Mol Pharmacol 2009

35334 Curtis AE, Cooke JH, Baxter JE, Parkinson JRC, Bataveljic A, Ghatei MA, Bloom SR,

354 Murphy KG: A kisspeptin-10 analog with greater in vivo bioactivity than kisspeptin-10. Am J

355 Physiol-Endoc M 2010;298:E296-E303.

35635 Seminara SB: Metastin and its g protein-coupled receptor, gpr54: Critical pathway

357 modulating gnrh secretion. Front Neuroendocrinol 2005;26:131-138.

35836 d'Anglemont de Tassigny X, Fagg LA, Carlton MB, Colledge WH: Kisspeptin can

359 stimulate gonadotropin-releasing hormone (gnrh) release by a direct action at gnrh nerve

360 terminals. Endocrinology 2008;149:3926-3932.

361

362 Figure 1; Effect of i.v. KISS1R agonist, FTM080, on plasma LH concentrations in anestrous

363 ewes $(n=3)$. a Response of circulating concentration of LH (mean \pm pooled SEM $=0.13)$ to i.v.

364 administration of VEH and FTM080 (500 pmol/kg BW; FTM080:500). There was an effect of

365 time $(\mathrm{P}=0.0019)$ and an interaction for FTM080 by time for LH $(\mathrm{P}=0.0009) .{ }^{*} \mathrm{p}<0.05$ vs.

366 VEH. b Effect of i.v. administration of VEH and FTM080 (500 pmol/kg BW; FTM080:500) on

367 AUC of LH concentrations from -60 to $0 \mathrm{~min}$ before (Pre-TRT) and from 0 to $60 \mathrm{~min}$ following

368 treatment (Post-TRT) (mean \pm pooled SEM $=6.29)$. AUCs with different superscripts differ $(\mathrm{p}<$

$3690.05)$.

370 Figure 2; Effect of i.v. KP-10 and FTM080, KISS1R agonist, on plasma LH concentrations in

371 anestrous ewes $(n=4)$. a Response of circulating concentration of LH (mean \pm SEM) to i.v.

372 administration of VEH (sterile water), KP-10 (500 pmol/kg), and FTM080 [500 (FTM080:500), 
3732500 (FTM080:2500), or 5000 (FTM080:5000) pmol/kg BW]. There was an effect of time (P <

$3740.0001)$ and an interaction of treatment and time $(\mathrm{P}<0.0001)$ on plasma LH concentrations. * $\mathrm{p}$

$375<0.05$ vs. VEH. $\uparrow \mathrm{p}<0.05$ vs. FTM080:500. ${ }^{\varphi} \mathrm{p}<0.05$ vs. FTM080:2500. b Effect of i.v.

376 administration of VEH (sterile water), KP-10 (500 pmol/kg BW), and FTM080:500,

377 FTM080:2500, or FTM080:5000 on AUC of plasma LH concentrations from -60 to 0 min before

378 (Pre-TRT) and from 0 to 60 min following treatment (1 hour Post-TRT) (mean $\pm \mathrm{SEM}$ ). There

379 was an effect of treatment $(\mathrm{P}<0.0001)$, period [pre-treatment ( -60 to $0 \mathrm{~min})$; post-treatment $(0$ to

$38060 \mathrm{~min}) ; \mathrm{P}<0.0001]$, and an interaction of treatment and period $(\mathrm{P}<0.0001)$ on area under the

381 curve (AUC) of plasma LH concentrations. AUCs with different superscripts differ $(p<0.05)$. 
1

Effect of i.v. KISS1R agonist, FTM080, on plasma LH concentrations in anestrous ewes (n $=3)$.

A) Response of circulating concentration of $\mathrm{LH}$ (mean \pm pooled SEM $=0.13$ ) to i.v. administration of VEH and FTM080 (500 pmol/kg BW; FTM080:500). There was an effect of time $(P=0.0019)$ and an interaction for FTM080 by time for $\mathrm{LH}(\mathrm{P}=0.0009)$. $* p<0.05$ vs. VEH. B) Effect of i.v. administration of VEH and FTM080 (500 pmol/kg BW; FTM080:500) on AUC of LH concentrations from - 60 to 0 min before (Pre-TRT) and from 0 to 60 min following treatment (Post-TRT) (mean \pm pooled SEM $=6.29$ ). AUCs with different superscripts differ ( $p$ $<0.05)$. 


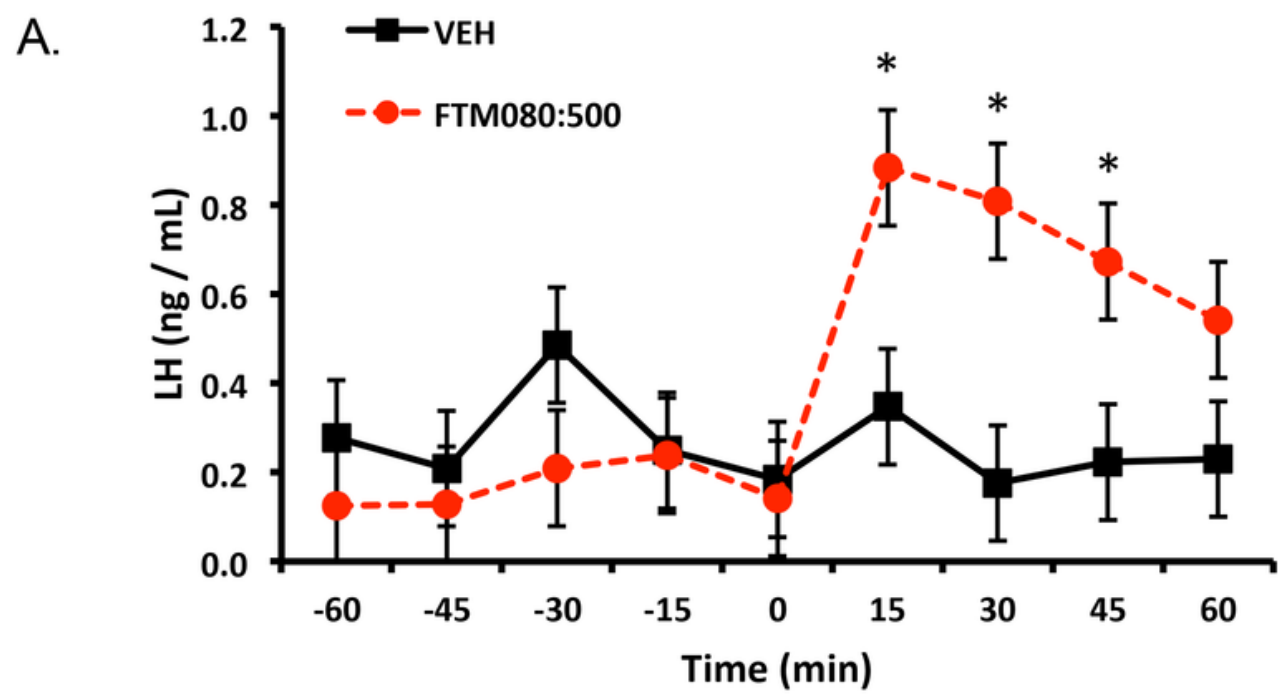

B.

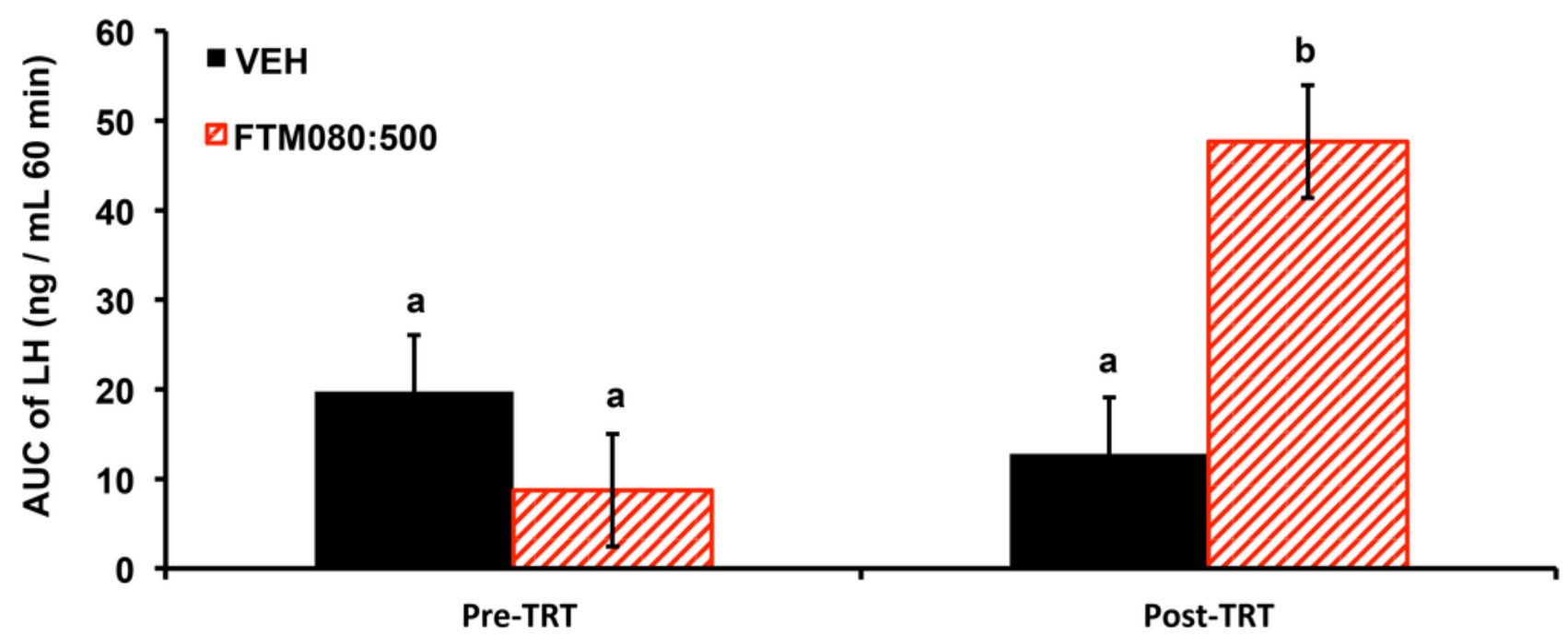




\section{2}

Effect of i.v. KP-10 and FTM080, KISS1R agonist, on plasma LH concentrations in anestrous ewes $(n=4)$.

A) Response of circulating concentration of $\mathrm{LH}$ (mean $\pm \mathrm{SEM}$ ) to i.v. administration of VEH (sterile water), KP-10 (500 pmol/kg), and FTM080 [500 (FTM080:500), 2500 (FTM080:2500), or 5000 (FTM080:5000) pmol/kg BW]. There was an effect of time $(\mathrm{P}<0.0001)$ and an interaction of treatment and time $(\mathrm{P}<0.0001)$ on plasma LH concentrations. $* p<0.05$ vs. VEH. $\dagger p<0.05$ vs. FTM080:500. ${ }^{\oplus} p<0.05$ vs. FTM080:2500. B) Effect of i.v. administration of VEH (sterile water), KP-10 (500 pmol/kg BW), and FTM080:500, FTM080:2500, or FTM080:5000 on AUC of plasma LH concentrations from -60 to 0 min before (Pre-TRT) and from 0 to 60 min following treatment (1 hour Post-TRT) (mean \pm SEM). There was an effect of treatment $(\mathrm{P}<0.0001)$, period [pre-treatment (-60 to $0 \mathrm{~min}$ ); post-treatment (0 to $60 \mathrm{~min})$; $\mathrm{P}$ $<0.0001]$, and an interaction of treatment and period $(P<0.0001)$ on area under the curve (AUC) of plasma LH concentrations. AUCs with different superscripts differ $(p<0.05)$. 

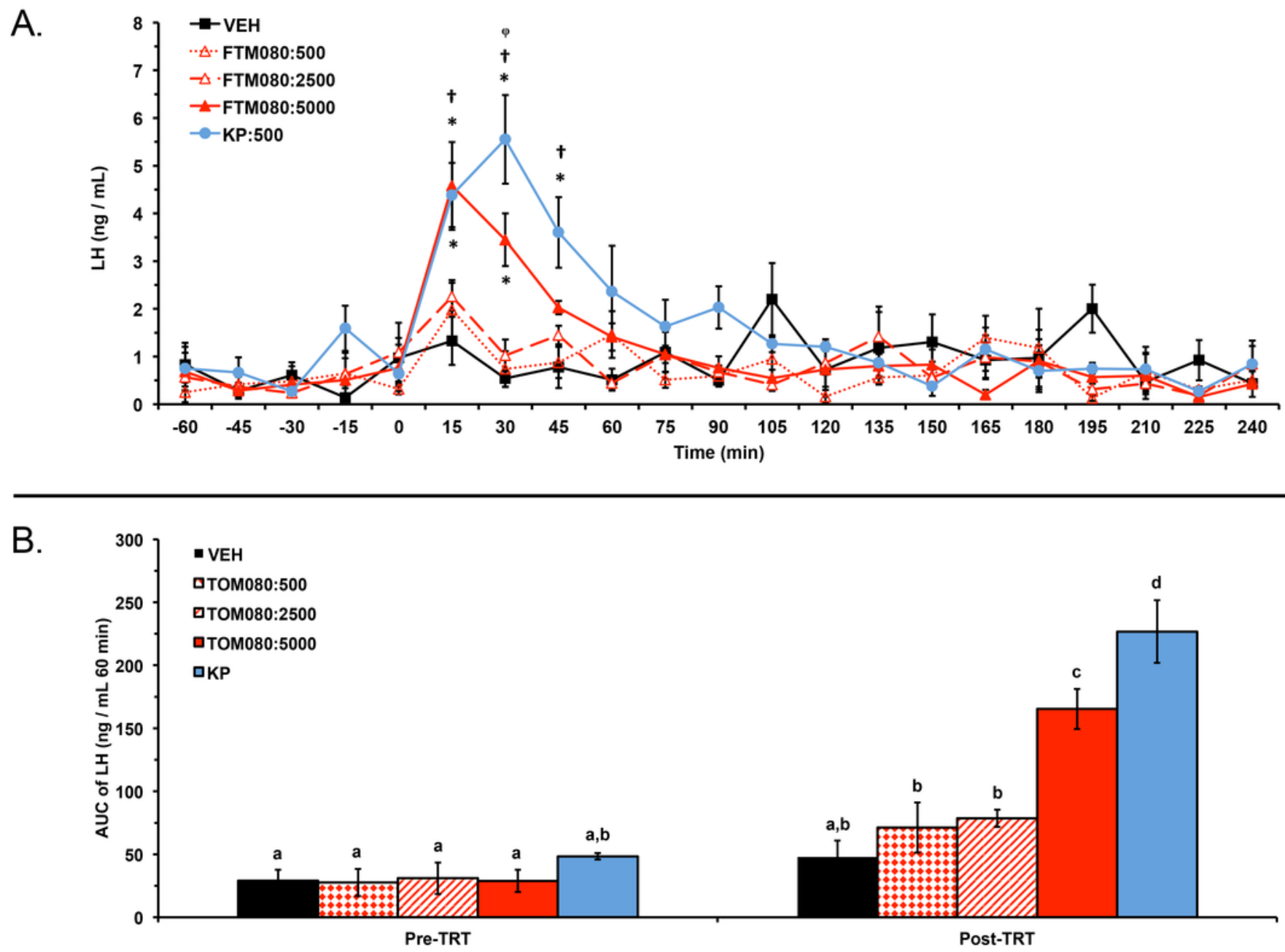